DOI: $10.20472 /$ TEC.2018.005.007

\title{
AYSE TUNA
}

Trakya University, Turkey

\section{ASSISTIVE TECHNOLOGY TOOLS FOR CHILDREN WITH LEARNING DISABILITIES}

\begin{abstract}
:
Children with learning disabilities are generally behind their age related peers in acquiring new skills required for daily activities and academic learning. Children with learning disabilities can learn and develop new skills, but compared to other children of the same age, they possibly need more time and practice. It has been shown that assistive technology tools are efficient ways to assist and teach children with different types of learning difficulties. In this study, state-of-the-art assistive technology tools that can be used for various educational goals are reviewed, novel approaches in this field are presented, and finally research challenges and future directions are reported.
\end{abstract}

\section{Keywords:}

Assistive technology tools, Children with learning disabilities, Educational goals, Research challenges, Future directions.

JEL Classification: 120 


\section{Introduction}

Assistive technology tools designed for children with learning disabilities are any device, system or software that helps to bypass or compensate for specific learning deficits (Stanberry, \& Raskind, 2009). Although they do not eliminate or cure those learning deficits, by allowing them to bypass areas of difficulty and benefit from their strengths, they can help such children reach their real potential (Lewis, 1998). For instance, audio books might be quite useful for students who struggle with reading but who have good listening skills. Although assistive technology tools compensate for children's skills deficits or area of disability, the use of such tools do not restrict receiving remedial instruction aimed at alleviating deficits.

Although assistive technology tools can help individuals at all ages, they are particularly effective for children. Assistive technology tools can successfully increase children's sense of independence and self-reliance. In addition, children with learning disabilities mostly experience higher success if they are enabled to use their abilities to work around their difficulties (Stanberry, \& Raskind, 2009). Hence, assistive technology tools play a key role in this regard.

There are many factors to be considered when evaluating assistive technology tools. First, a child's specific challenges and needs and skills that the child struggles with should be found out. Second, the child's strengths should be determined so that assistive technology tools can be used to compensate for the child's disability. Finally, if present, based on the child's skill, interest and experience in the selected tool, settings and situations should be determined. In this study, we review assistive technology tools that can be used for educational goals and present novel approaches in the roles of assistive technology tools in this field. The remainder of the paper is as follows. A brief literature survey is given in Section 2. Section 3 presents research challenges and state future directions in this field. Finally, Section 4 concludes the paper.

\section{Literature Review and Classification}

For children with learning disabilities, assistive technology tools replace an ability that is either impaired or missing, and provide the support needed to perform a task successfully (Quenneville, 2001). In addition, in general education classrooms, the use of assistive technology tools promotes belonging and interactive participation for students with learning disabilities (Bryant, \& Bryant, 1998). Moreover, it increases motivation and the frequency of assignment completion (Bahr, Nelson, \& VanMeter, 1996).

Many types of learning disabilities can be addressed using assistive technology tools. For example, a student with difficulty in writing can prepare an electronic document using speech recognition software or a student with dyslexia may benefit from screen readers. Assistive technology tools can help children who struggle with the following difficulties. 
- Listening: Children who have difficulties in processing and remembering spoken language may benefit from certain assistive technology tools in various settings including a class lecture (Merbler, Hadadian, \& Ulman, 1999).

- Reading: Children who have difficulty in reading may benefit from text-to-speechbased assistive technology tools (MacArthur, 1996).

- Writing: Assistive technology can help children who have difficulty in writing. For instance, speech-to-text software eliminates the burden of writing (Schwartz, 2005; Stanberry, \& Raskind, 2009). On the other hand, proofreading software assists in proper spelling, word usage, and grammar.

- Organisation and memory: Certain assistive technology tools can help students plan, organise and manage their calendar, schedule, contact information and task lists, and allow taking miscellaneous notes (Stanberry, \& Raskind, 2009; Schwartz, 2005).

- Mathematics: Assistive technology can help students with difficulties in computing, organising, aligning, and copying mathematical problems (Schwartz, 2005).

The abovementioned difficulties can be addressed with different kinds of assistive technology tools. Although traditionally assistive technology tools were based on electronic devices and computer hardware and software solutions, currently there are many Internet based assistive technology tools. Table 1 lists assistive technology tools and their roles in addressing learning disabilities.

Table I. Assistive technology software/device/tool designed to address learning disabilities

\begin{tabular}{|l|l|}
\hline Software/Device/Tool & Function \\
\hline Abbreviation expander & $\begin{array}{l}\text { When combined with word processing software, it enables } \\
\text { users to create, store, and reuse abbreviations for one or more } \\
\text { words or phrases (Gregg, 2009). }\end{array}$ \\
\hline Alternative keyboard & $\begin{array}{l}\text { It has a special overlay but functions as a standard keyboard } \\
\text { (Laabidi et al., 2014). }\end{array}$ \\
\hline Audio book & $\begin{array}{l}\text { Recorded books available in a range of digital formats allow } \\
\text { students to listen to text. }\end{array}$ \\
\hline Data manager & $\begin{array}{l}\text { It helps users plan, organise, store, and retrieve their } \\
\text { calendars, task lists, contact data, and other information in } \\
\text { electronic form (Stanberry, \& Raskind, 2009). }\end{array}$ \\
\hline Electronic & It makes organising, aligning, and working through \\
\hline
\end{tabular}




\begin{tabular}{|c|c|}
\hline $\begin{array}{l}\text { mathematics } \\
\text { worksheet }\end{array}$ & mathematical problems easier for users (Adebisi et al., 2015). \\
\hline $\begin{array}{l}\text { Freeform database } \\
\text { software }\end{array}$ & $\begin{array}{l}\text { When combined with other software applications, it allows } \\
\text { users to take electronic notes by typing relevant information } \\
\text { briefly. Later on, the user can restore the information by typing } \\
\text { a few fragments of the original electronic note (Schwartz, } \\
\text { 2005). }\end{array}$ \\
\hline $\begin{array}{l}\text { Graphic organiser and } \\
\text { outlining software }\end{array}$ & $\begin{array}{l}\text { It enables users to dump information quickly in an unorganised } \\
\text { manner and later on allow them to organise the information into } \\
\text { the desired order and appropriate categories (Montgomery, } \\
\text { 2009). }\end{array}$ \\
\hline $\begin{array}{l}\text { Optical character } \\
\text { recognition } \\
\text { software/device }\end{array}$ & $\begin{array}{l}\text { It allows users to scan printed materials and then convert the } \\
\text { images of the printed materials into machine-encoded text } \\
\text { (Quenneville, 2001). }\end{array}$ \\
\hline $\begin{array}{l}\text { Personal FM listening } \\
\text { system }\end{array}$ & $\begin{array}{l}\text { It consists of a wireless transmitter (with microphone) worn by } \\
\text { the speaker and a receiver (with earphone) worn by the } \\
\text { listener. It transmits the speaker's voice directly to the listener's } \\
\text { ear so that the listener can concentrate more on what is said } \\
\text { (Chisolm et al., 2007). }\end{array}$ \\
\hline $\begin{array}{l}\text { Portable word } \\
\text { processor }\end{array}$ & $\begin{array}{l}\text { It is a lightweight device with a keyboard to help children who } \\
\text { have difficulties in writing (Quenneville, 2001). }\end{array}$ \\
\hline Proofreading software & $\begin{array}{l}\text { It scans text documents and alerts users to possible errors } \\
\text { (MacArthur, 1996). }\end{array}$ \\
\hline Screen reader & $\begin{array}{l}\text { It allows users to read the text displayed on the computer } \\
\text { screen with a speech synthesiser or Braille display (Hersh, \& } \\
\text { Johnson, 2008). }\end{array}$ \\
\hline $\begin{array}{ll}\text { Speech } & \text { recognition } \\
\text { software } & \end{array}$ & $\begin{array}{l}\text { When users dictate into a microphone, it converts the spoken } \\
\text { words to text. }\end{array}$ \\
\hline Talking calculator & $\begin{array}{l}\text { Using its built-in speech synthesiser, it enables users to verify } \\
\text { the accuracy of keys pressed, gives them auditory feedback } \\
\text { while making calculations, finally it announces the calculation } \\
\text { results (Stanberry, \& Raskind, 2009). }\end{array}$ \\
\hline Talking spell checker & $\begin{array}{l}\text { It allows users to select appropriate words so that possible } \\
\text { spelling errors can be corrected while the text document is } \\
\text { being prepared (Ott, 2007). }\end{array}$ \\
\hline
\end{tabular}




\begin{tabular}{|l|l|}
\hline $\begin{array}{l}\text { Variable-speed tape } \\
\text { recorder }\end{array}$ & $\begin{array}{l}\text { It allows users to capture spoken information and play it back at } \\
\text { any speed later (Sedlak, \& Sedlak, 1985). }\end{array}$ \\
\hline $\begin{array}{l}\text { Word prediction } \\
\text { software }\end{array}$ & $\begin{array}{l}\text { It predicts words users intend to type based on grammatically } \\
\text { correct usage of words, frequency of use, and most recently } \\
\text { used words (MacArthur, 1996; Quenneville, 2001). }\end{array}$ \\
\hline
\end{tabular}

\section{Research Challenges and Future Directions}

Assistive technology tools range from simple, low-tech ones to sophisticated, high-tech ones, and can be used to either support learning or bypass a challenging task. Assistive technology tools need to be integrated into classroom setting after an extensive training so that they can be effective.

Although assistive technology tools are commonly viewed as useful, use and knowledge of assistive technology tools are limited. In addition, training to use assistive technology tools and resource availability for assistive technology integration is limited, too. The main reasons of these are inadequate teacher training for assistive technology and the rate of technology change.

As given in (Cook, \& Friend, 1996), in educational settings collaboration has many dimensions and in collaboration with teachers, parents, and students, assistive technology specialists should evaluate each student's technology needs. Since each student's motivation and reaction to a set of adaptations may be quite different, the collaboration leads to determine an appropriate match among tools, specific demands, and student characteristics (Quenneville, 2001). As soon as the appropriate assistive technology tool is determined, the assistive technology specialists train the teachers, parents, and students so that the teachers and students can integrate the tool into their classroom routines.

One of the most important use cases of assistive technology is the development of individualised educational plans. For this goal, the collaboration of planning teams is a must so that the team members should determine the effectiveness of current technology and closely monitor the students (Quenneville, 2001). In this way, the necessary modifications are realised and the changing abilities of the individuals are reflected.

\section{Conclusion}

Assistive technology tools can help students with learning disabilities break down barriers to learning and compensate for challenges in learning. In addition, they can increase motivation, reduce frustration, promote peer acceptance, and enhance productivity of students with learning disabilities. As presented in the paper, there are different assistive technology tools that can be used for various educational goals and be used to bypass or 
compensate for specific learning deficits. The real potential of assistive technology for students with learning disabilities has not been explored yet and in parallel with the significant advancements in technology, more efficient assistive technology tools will possibly be designed to assist children with learning difficulties in their educational progress.

\section{References}

Adebisi, R. O., Liman, N. A., \& Longpoe, P. K. (2015). Using Assistive Technology in Teaching Children with Learning Disabilities in the 21st Century. Journal of Education and Practice, 6(24), pp. 14-20.

Bahr, C. M., Nelson, N. W., \& VanMeter, A. M. (1996). The effects of text-based and graphics-based software tools on planning and organizing of stories. Journal of Learning Disabilities, 29, pp. 355370.

Bryant, D. P., \& Bryant, B. R. (1998). Using assistive technology adaptations to include students with learning disabilities in cooperative learning activities. Journal of Learning Disabilities, 31, pp. 41-54.

Chisolm, T. H., Noe, C. M., McArdle, R., \& Abrams, H. (2007). Evidence for the Use of Hearing Assistive Technology by Adults: The Role of the FM System. Trends in Amplification, 11(2), pp. 73-89.

Cook, L., \& Friend, M. (1996). The fundamentals of collaboration. In Interactions: Collaboration skills for school professionals (pp. 1-20), Witzling, L. W. (Eds.). New York: Longman.

Gregg, N. (2009). Adolescents and adults with learning disabilities and ADHD: assessment and accommodation. Warriewood, NSW: Footprint Books.

Hersh, M., \& Johnson, M. A. (2008). Assistive Technology for Visually Impaired and Blind People (1st ed.). Springer Publishing Company.

Laabidi, M., Jemni, M., Ayed, B. J., Brahim, H. B., \& Jemaa, A. B. (2014). Learning technologies for people with disabilities. Journal of King Saud University - Computer and Information Sciences, 26(1), pp. 2945.

Lewis, L. B. (1998). Assistive technology and learning disabilities: Today's realities and tomorrow's promises. Journal of Learning Disabilities, 31, pp. 16-26.

MacArthur, C. A. (1996). Using technology to enhance the writing processes of students with learning disabilities. Journal of Learning Disabilities, 29, pp. 344-354.

Merbler, J., Hadadian, A., \& Ulman, J. (1999). Using assistive technology in the inclusive classroom. Preventing School Failure, 43, pp. 113-118.

Montgomery, D. (Eds). (2009). Able, Gifted and Talented Underachievers (Second Edition). John Wiley \& Sons Ltd.

Ott, P. (2007). How to Manage Spelling Successfully. London: Routledge.

Quenneville, J. (2001). Tech Tools for Students with Learning Disabilities: Infusion into Inclusive Classrooms. Journal of Preventing School Failure, 45(4), pp. 167-170.

Schwartz, D. (2005). Including Children with Special Needs: A Handbook for Educators and Parents (Handbooks for Educators and Parents). Greenwood.

Sedla, R. A., \& Sedlak, D. M. (1985). Teaching the Educable Mentally Retarded. SUNY Series in Special Education. 
Stanberry, K., \& Raskind, H. (2009). Assistive Technology for Kids with Learning Disabilities: An Overview. Retrieved

February 04 , 2018,

from http://www.Idonline.org/article/Assistive_Technology_for_Kids_with_Learning_Disabilities\%3A_An_O verview

UNICEF.

(2015). Assistive

Technology for Children with Disabilities: Creating Opportunities for Education, Inclusion and Participation. World Health Organization. 